\title{
CONSERVATIVE THERAPIES FOR HEMORRHAGIC RADIATION PROCTITIS: A REVIEW
}

\author{
Guilherme Cotti, Victor Seid, Sérgio Araujo, Afonso Henrique Silva e Souza Jr., \\ Desidério Roberto Kiss and Angelita Habr-Gama
}

COTTI G et al. - Conservative therapies for hemorrhagic radiation proctitis: a review. Rev. Hosp. Clín. Fac. Med. S. Paulo 58(5):284-292, 2003.

Chronic radiation proctitis represents a challenging condition seen with increased frequency due to the common use of radiation for treatment of pelvic cancer. Hemorrhagic radiation proctitis represents the most feared complication of chronic radiation proctitis. There is no consensus for the management of this condition despite the great number of clinical approaches and techniques that have been employed. Rectal resection represents an available option although associated with high morbidity and risk of permanent colostomy. The effectiveness of nonoperative approaches remains far from desirable, and hemorrhagic recurrence represents a major drawback that leads to a need for consecutive therapeutic sessions and combination of techniques. We conducted a critical review of published reports regarding conservative management of hemorrhagic chronic radiation proctitis. Although prospective randomized trials about hemorrhagic radiation proctitis are still lacking, there is enough evidence to conclude that topical formalin therapy and an endoscopic approach delivering an argon plasma coagulation represent available options associated with elevated effectiveness for interruption of rectal bleeding in patients with chronic radiation proctitis.

DESCRIPTORS: Proctitis. Radiation. Hemmorrhagic. Conservative. Treatment.

Radiotherapy (RDT) techniques have become primary treatments for pelvic organ cancer, subsequent to improvements in these techniques over the past few decades. After pelvic irradiation, the rectum is one of the most commonly injured organs due to its fixed position ${ }^{1-3}$. Its anatomic relationships with the uterine cervix and prostate make it impossible not to irradiate the rectum during RDT regardless of the target organ ${ }^{4}$. Radiation proctitis (RP) is an adverse effect of RDT to the rectum, and its prevention and treatment have become topics of debate. The main purpose of this review is to discuss current therapies for radiation-induced injury to the rectum, mainly in its hemorrhagic form.

\section{GENERAL CONSIDERATIONS}

Radiation proctitis can be classified as acute or chronic. Acute radiation proctitis (ARP) can begin during or shortly after irradiation but usually resolves in up to 6 months. It is characterized by diarrhea, intermittent bleeding, nausea, abdominal pain, mucous discharge, and constipation or even urinary symptoms. Histological alterations are usually confined to the mucosa $a^{5}$, and in general, has a short

From the Department of Gastroenterology, Hospital das Clínicas, Faculty of Medicine, University of São Paulo, São Paulo/SP Brazil.

Received for publication on May 26, 2003. duration and improves with conservative measures. However, about $20 \%$ of the patients with RP require interruption of the treatment for 1 to 2 weeks in order to improve clinical status. Following this acute episode most of the patients remain asymptomatic, but up to $20 \%$ of this contingent will develop chronic radiation proctitis (CRP) ${ }^{6}$. The development of CRP may take up to 2 years and has no relationship with the occurrence of $\mathrm{ARP}^{7}$.

During the course of radiotherapy, virtually all patients present symptoms related to ARP. However, such symptoms usually subside from 2 to 3 months after the end of RDT ${ }^{8}$. Nevertheless, $2 \%$ to $10 \%$ of the patients develop CRP, usually 6 to 24 months af- 
ter RDT, but clinical symptoms may appear up to 30 years after treatment $^{9,10}$.

Chronic radiation proctitis has several forms of clinical presentation, including mucous rectal discharge, diarrhea, urgency, pain, and bleeding. Recto-vaginal fistula, enteric fistula, cutaneous fistula, perforation, and rectal stenosis can rarely occur. Histological alterations are mainly of a vascular nature, such as subintimal fibrosis and platelet thrombi in the arterioles of the submucosa with fibrosis of connective tissue ${ }^{5}$.

The development of RP is directly related to the dose of radiation, the irradiated volume, type of radiation exposure, dose fraction regimens, and the interval between sessions. Smith et al. reported a $20 \%$ incidence of RP with a radiation dose up to $7.500 \mathrm{Cgy}$ and a $60 \%$ incidence of RP with doses greater than $7.500 \mathrm{Cgy}^{11}$.

Other factors predispose to RP, including previous abdomino-pelvic surgery, obesity, diabetes mellitus, hypertension, atherosclerosis, and simultaneous chemotherapy. In 1997, Bertuccelli et al. studied the effect of the combination of chemotherapy with RDT in the treatment of rectal cancer and observed an increase in incidence of severe diarrhea in the group that received RDT plus chemotherapy when compared to the group that underwent RDT alone (20\% versus $10 \%)^{12}$.

Endoscopic findings of RP are also variable. Since 1923, when the first endoscopic findings were reported, there have been many attempts to establish a standardized endoscopic approach to its diagnosis ${ }^{13}$. Paleness, erythema, vascular abnormalities, and ulcerations are easily recognized alterations. However, in order to correlate the clinical picture to endoscopic findings, Wachter et al. proposed a score for RP based on terminology of the World Organization of Digestive Endoscopy (OMED) and its
5 main alterations, namely telangiectasias, congestion, ulcerations, stenosis, and necrosis ${ }^{14}$.

The prognosis of RP remains obscure. Gilinsky et al., in 1983, reported on 88 patients with RP followed for more than 8 years. Fifty percent presented slight to moderate symptoms with distinct endoscopic findings that resolved spontaneously in 2 years ${ }^{10}$. Nevertheless, 17 patients presented refractory symptoms. Cho et al. observed that 19 out of 101 patients developed $\mathrm{RP}$ after radiation therapy for prostate cancer $^{15}$.

Despite the fact that the incidence of RP tends to increase with time, RP still lacks research and attention. It should be noted that no consensus exists about its clinical and endoscopic evaluation and its natural history. Its behavior and prognosis are not completely known.

Rectal bleeding due to RP usually represents a chronic condition, and anemia is a common finding; sometimes bleeding may be severe. Several treatments for this presentation have been used, and as a result of its high recurrence rate, they were rarely utilized in a cyclic manner, which makes their evaluation difficult. We opted to review and analyze the results of conservative treatments of hemorrhagic CRP.

\section{Steroids}

In 1976, Goldstein et al. observed clinical improvement of a patient with radiation-induced proctitis who received salicylazosulfapyridine in combination with prednisone ${ }^{16}$. Subsequently, other studies were developed in an attempt to evaluate the use of steroids as a therapeutic alternative for $\mathrm{RP}$, alone and also in combination with other modalities.

In 1984, Ben Bouali et al. demonstrated clinical and endoscopic improvement in 4 out of 33 patients treated with daily rectal administration of $5 \mathrm{mg}$ of betamethasone in combination with diphenoxylate ${ }^{17}$. In 1977 , Pajares et al. also observed a decrease of rectal bleeding after administration of prednisone ${ }^{18}$. More recently, Triantafillidis et al. reported 5 patients treated for RP with enemas containing $5 \mathrm{mg}$ of betamethasone without any clinical improvement ${ }^{19}$.

In a prospective randomized study, Kochhar et al. compared the use of enemas containing prednisolone and $3 \mathrm{~g}$ of oral sulfasalazine in 18 patients to the use of enemas containing sucralfate in combination with an oral placebo in 19 patients for 4 weeks ${ }^{20}$. Clinical improvement was appraised by a score based on the number of bowel movements, bleeding, and tenesmus. Therapy with sucralfate was more efficient, better tolerated, and cheaper.

Another prospective randomized study in mice analyzed administration of $90 \mathrm{mg}$ of hydrocortisone and showed endoscopic improvement and better tolerance when compared with betamethasone enemas ${ }^{21}$.

Steroids have been used for many years in the treatment of RP despite the absence of larger and well-designed studies ${ }^{22}$. Moreover, steroids were not able to achieve sustained resolution of symptoms for patients with CRP.

\section{Aminosalicylates}

Derivatives of 5-aminosalicylic acids (5ASA), also known as aminosalicylates, have been the object of research in treatment of RP since the studies of Menie et al. in 1975 showed efficiency of the 5-aminosalicylic acid drugs versus placebo in the prevention of diarrhea in patients undergoing pelvic RDT, as well as studies for their previous use in the management of inflammatory proctitis. Aminosalicylates act in reducing the production of prostaglandins in the intestinal mu$\cos a^{20}$. 
Goldstein et al. demonstrated the effectiveness of oral sulfasalazine in combination with steroid enemas in 1 patient $^{16}$. Bem Bouali et al. demonstrated that administration of sulfasalazine, in oral or enema form, provided clinical and endoscopic improvement in $60 \%$ of patients ${ }^{17}$. In 1989, Ladas et al. demonstrated that administration of sulfasalazine in combination with sucralfate enemas was effective in controlling rectal bleeding and promoted endoscopic improvement in 1 patient with CRP. ${ }^{23}$

On the other hand, in 1989, Baum et al. showed that daily administration of enemas containing 5ASA for a period of 2 to 6 months was not able to induce clinical, endoscopic, or histological improvement in 4 patients with $\mathrm{CRP}^{24}$. Another study of 5 patients performed by Triantafillidis et al. demonstrated no improvement over 5ASA enemas. ${ }^{19}$

We believe that multicenter prospective randomized studies of aminosalicylates are needed to confirm their role in the management of RP, but available evidence suggests that they are not effective.

\section{Sucralfate}

Sucralfate is an aluminum salt that adheres to the mucous membrane, promoting the formation of a protective barrier that has been used for many years in the treatment of peptic ulcers. Its possible effectiveness for inflammatory proctitis and for colonic bleeding after endoscopic polypectomy is also under investigation.

The cytoprotective action of sucralfate seems to be derived from the production of prostaglandins and promotion of epithelial cell proliferation. In animal models of colitis in mice, rectal administration of sucralfate induced high E2-prostaglandin levels and increased cellularity of the colonic mucosa ${ }^{25}$.
The best route for sucralfate administration remains controversial. In 1988, Kochhar et al. used enemas containing $2 \mathrm{~g}$ of sucralfate in 4 patients with hemorrhagic RP and demonstrated reduced bleeding ${ }^{26}$. A previous study by Henriksson et al. in 1987 showed the usefulness of oral sucralfate administered for 2 to 6 weeks after RDT in the reduction of bowel movements, mucous discharge, and rectal bleeding after 1 year $^{27}$. Another study by Kochhar in 1991 demonstrated the superiority of topical sucralfate over steroid enemas administered in combination with sulfasalazine ${ }^{20}$.

In 1996, Stockdale and Biswas reported that administration of enemas containing $2 \mathrm{~g}$ of sucralfate in a patient with hemorrhagic RP resulted in longterm control of CRP as revealed from 4 years of follow-up ${ }^{28}$. Again in 1996, Tada et al. demonstrated endoscopic improvement of CRP in 6 out of 7 patients treated with $2 \mathrm{~g}$ sucralfate enemas. ${ }^{29}$

In 1997, O'Brien et al. published the negative effect of a sucralfate suspension for prevention of $\mathrm{ARP}^{30}$. In this multicenter Australian study, 86 patients were randomized into 2 groups: 1 group received $3 \mathrm{~g}$ sucralfate enemas and the other group received a placebo. Enemas were administered once daily for a period of 2 weeks after RDT. Sucralfate enemas did not reduce symptoms associated with ARP and therefore should not be recommended in clinical practice.

In 1998, Sasai et al. published 3 cases of patients with hemorrhagic RP who had undergone previous sulfasalazine and steroid treatment without success. They experienced significant improvement of rectal bleeding after daily administration of $4 \mathrm{~g}$ of sucralfate during 1 to 2 months ${ }^{31}$. The authors emphasized the advantages of oral sucralfate, which include good tolerance and few side effects associated with control of the symptoms for a long period.
More recently in 1999, Kochhar et al. demonstrated that topical sucralfate produced sustained resolution of symptoms, in agreement with previous authors $^{32}$. Stockdale and Biswas ${ }^{28}$ studied 26 patients with hemorrhagic RP that were treated with 2 g sucralfate enemas twice daily. The patients were examined every 4 weeks in the first 16 weeks of treatment and after that at an interval of 8 to 12 weeks. Twenty patients had a significant reduction of bleeding in the first 4 weeks of treatment, as did another 4 patients after 16 weeks. At a mean of 45 weeks, 7 patients had some kind of symptomatic recurrence. However, bleeding ceased soon after the sucralfate treatment was reintroduced.

\section{Short-Chain Fatty Acids (SCFA)}

During the past few years, many studies have been performed on shortchain fatty acids (SCFA) so that knowledge regarding these substances has increased. Short-chain fatty acids are organic acids containing from 1 to 6 carbons that are a product of bacterial metabolism of some carbohydrates in the colon; they are the main source of energy for colonocytes. Butyrate is the most important SCFA and is preferentially metabolized by colonic mucosa when compared to propionate and acetate. The dependence of the colon related to the oxidation of SCFA increases towards the rectum, and $70 \%$ of the oxygen consumed by the colonic epithelial cells is used in the oxidation of $\mathrm{SCFA}^{33}$.

The effect of SCFA on rectal and colonic mucosa has been tested in patients with RP in an attempt to obtain healing of mucous lesions ${ }^{33,34}$. In 1999 , Pinto et al. in a double-blind randomized placebo-controlled trial studied 19 patients with $\mathrm{CRP}^{35}$. They demonstrated a beneficial effect from administration of 2 daily enemas with 60 mmol SCFA for 5 weeks in compari- 
son with the administration of an isotonic solution. There was a significant decrease of rectal bleeding with SCFA as well as an endoscopic improvement. In 1995, Mamel et al. also demonstrated the efficacy of enemas containing $60 \mathrm{~mL}$ of SCFA twice daily for 4 weeks in the improvement of 6 patients with $\mathrm{CRP}^{36}$. In 1996, Al Sababagh et al. using the same solution described in the previous studies achieved clinical, endoscopic, and histological improvement in 7 patients with hemorrhagic $\mathrm{RP}^{37}$.

These results were not reproduced by Chen et al. in a prospective study, where they evaluated the evolution of 12 patients with hemorrhagic CRP for 2 weeks and did not find any significant difference in clinical, endoscopic, and histological aspects of patients treated with $\mathrm{SCFA}^{38}$.

More recently, Talley et al. compared daily administration of 2 enemas with $60 \mathrm{~mL}$ of butyrate in a concentration of $40 \mathrm{mmol}$ to placebo for 2 weeks in a randomized double-blind study of 15 patients with CRP. They found no benefit from $\mathrm{SCFA}^{39}$.

In 1998, Cook and Sellin performed a literature review about SCFA in the management of colitis ${ }^{33}$. Regarding RP, the authors observed that studies showed early reduction of bleeding episodes, but SCFA had no influence in other symptoms such as chronic pain and tenesmus.

In spite of the great progress in the knowledge of the structure, metabolism, and action of SCFA, there is still need for additional data to confirm its effectiveness. Because of these conflicting data, there are no commercial preparations available for clinical use.

\section{Formalin}

The use of formalin in the management of RP emerged from its use in the treatment of bleeding tumors of the bladder and radiation cystitis ${ }^{40,41,2}$.
In 1986, Rubinstein et al. successfully used a rectal wash with formalin for the first time in the treatment of $\mathrm{RP}^{42}$. The authors reported a 71-yearold patient irradiated for bladder cancer who developed diffuse hemorrhagic RP. The patient underwent general anesthesia and the rectum was irrigated with two liters of $3.6 \%$ formalin for 15 minutes, followed by irrigation with saline. An insufflated vesical probe was used in order to protect the sigmoid colon. The procedure was repeated after 2 weeks and after 3 months. Bleeding episodes immediately ceased and the patient was asymptomatic after 14 months.

After these results, many authors initiated treatments of hemorrhagic CRP with formalin. In 1993, SeowChoen et al. used formalin in 8 patients with hemorrhagic CRP refractory to steroids and with a constant need for blood transfusions ${ }^{43}$. In this study, a $4 \%$ solution-soaked gauze was applied to the rectum through a rectoscope. Patients underwent regional anesthesia and had their perianal skin protected to avoid direct contact with the formalin. Contact between the gauze and rectal mucosa was maintained until the bleeding stopped (from 2 to 3 minutes). Bleeding ceased in 7 patients after a single session, while another patient needed an additional application.

In 1995, the same authors confirmed the effectiveness of direct application of formalin solution soaked

Table 1 - Summarized results of patients with hemorrhagic radiation proctitis treated with formalin instillation.

\begin{tabular}{llll}
\hline Author & Number of patients & Follow-up (months) & Response \\
\hline Seow-Choen et al. ${ }^{43}, 1993$ & 8 & 4 & $88 \%$ \\
Biswal et al. ${ }^{47}, 1995$ & 16 & 11 & $81 \%$ \\
Isenberg et al. ${ }^{48}, 1994$ & 2 & 3 & $100 \%$ \\
Salvati et al. ${ }^{49}, 1996$ & 10 & Not reported & $100 \%$ \\
Roche et al. ${ }^{50}, 1996$ & 6 & 12 & $100 \%$ \\
Faragher et al. ${ }^{51}, 1997$ & 7 & 10 & $100 \%$ \\
\hline
\end{tabular}

gauze in 29 patients followed for 12 months ${ }^{44}$. In this study, rectal bleeding ceased right after application in 17 patients. Four patients needed a second application (72\% success rate). The 5 remaining patients obtained only partial improvement.

The instillation technique proposed by Rubinstein et al. was modified by 2 groups. One of them used rectal instillation with $4 \%$ formalin after placement of a Foley catheter in order to delineate the superior limit of the instillation and protect the normal intestine in 14 patients resistant to steroid and/or sulfasalazine treatment ${ }^{45}$. Treatment was well tolerated, and 11 patients needed 2 applications while other 3 patients needed 3 sessions. After 6 months, 9 patients were asymptomatic $(64 \%), 3$ patients had incomplete resolution of symptoms, and 2 had no improvement. Saclarides et al. reported a study in which aliquots of $50 \mathrm{~mL}$ of $4 \%$ formalin were instilled into the rectum for 30 seconds each, with a total of 400 to $500 \mathrm{~mL}$ per session in 16 patients. They achieved complete symptom control in $81 \%$ of after 1 or 2 applications ${ }^{46}$. Four patients developed fissures in the anal verge and 1 developed tenesmus.

The technique of soaked gauze proposed by Seow-Choen was revised by 5 groups, with a total of 41 patients. Complete success rate ranged from $80 \%$ to $100 \%$ after 1 to 4 sessions (Table 1$)^{43,47-51}$.

Recently, in an Australian study, a 
combination of formalin and $\mathrm{Nd}: \mathrm{YAG}$ (neodymium yttrium-aluminum-garnet) laser was used in 14 patients $^{52}$. First, the patients underwent an endoscopic $\mathrm{Nd}$ :YAG laser procedure and then were treated with a formalin application as described by Seow-Choen. A single session was enough for 9 patients, 2 sessions were necessary for 3 patients, and 3 sessions forthe other 2 patients. After a 3-year follow-up, 10 (71\%) patients had no rectal bleeding, and another one had a significant decrease in bleeding episodes. Two patients required an operation to manage their symptoms.

After these first published series with formalin as a therapeutic alternative for hemorrhagic RP, investigators have been trying to determine the best concentration and form of its application as well as its side effects. In low concentrations, formalin is not toxic. However, high concentrations can result in severe toxic effects. Additionally, the nutritional state and smoking can alter blood levels of formalin. The only reported case of intoxication after rectal irrigation occurred due to accidental infusion of $100 \mathrm{~mL}$ of $10 \%$ formalin. The patient developed chronic colitis that resolved after 2 months ${ }^{53}$.

Evidence suggests that formalin is very effective in the treatment of hemorrhagic CRP, mainly in cases in which the 2 distal thirds of the rectum are affected. Other advantages of formalin application are low cost, low incidence of side effects, availability, and its easy manipulation.

\section{Endoscopic}

Endoscopic management of CRP is based on endoscopic coagulation induced by Nd:YAG laser, electrocoagulation, or argon plasma coagulation (APC).

The first description of Nd:YAG laser use in CRP was published by Leuchter in 1982. The author reported the success of this technique for the control of rectal hemorrhage after 4 applications in 1 patient in which he cally identified vascular alterations ${ }^{54}$.

The effectiveness of the Nd:YAG laser was confirmed by other authors in series with a total of 98 patients. One of the most important was published by Viggiono et al. in 1993 reporting on 47 patients. After an average of 2 sessions (7950 joules each), a $79 \%$ control rate of rectal bleeding was achieved ${ }^{55}$.

In 1998, Swaroop et al. described the technique for therapy with a Nd:YAG laser ${ }^{56}$. Initially, the patient should undergo a complete colonoscopy to determine the extent of the lesion. With an initial energy of $40 \mathrm{~W}$ and a maximum pulse duration of half a second, the laser is applied without direct contact to the mucosa, but with its tip less than $1 \mathrm{~cm}$ away from it. All visible lesions should be coagulated in the distal direction. A white clot should be obtained as a final effect, avoiding cavities in the intestinal mucosa. Complications of Nd:YAG laser therapy include tenesmus, abdominal pain, rectal stenosis, prostatitis, and recto-vaginal fistula ${ }^{55,57}$.

Laser therapy for hemorrhagic CRP was supplanted by argon plasma coagulation (APC) because it is more readily available, cheaper, and requires fewer safety precautions, while still yielding excellent results. Argon plasma coagulation is a diathermy method in which there is no direct contact between the electrode and the patient, and high frequency energy is used 30 shots driven to the endoscopi-

applied to the tissue through the ionized argon. This technique is very suitable for coagulation of large bleeding surfaces and features the advantage of limited penetration ( 2 to 3 millimeters), minimizing the risks of perforation, stenosis, and fistulization. The char generated with APC promotes an interruption of the current passing through the tissue while Nd:laser continues to penetrate the tissue until it is switched off.

Since the first use of APC with a flexible endoscope described by Grund et al. ${ }^{58}$ in 1994, it has gained a wide popularity. Silva et al. in a study of 28 patients obtained good results ${ }^{59}$ and emphasized the possibility of application of the argon plasma in any direction, resulting in excellent access to vascular lesions. Gas flow eliminates oxygen from the coagulation area, avoiding carbonization of the tissue and smoke production. Moreover, light produced by gas ionization promotes good visual control of the procedure. Those authors also propose the use of $50 \mathrm{~W}$ of energy and a $1.5 \mathrm{~L} / \mathrm{min}$ flow for the procedure. Fantin et al. demonstrated the effectiveness of APC in 7 patients after 2 to 4 applications, using as parameters an energy of $60 \mathrm{~W}$ and a flow of $3 \mathrm{~L} / \mathrm{min}^{60}$.

Other authors have also obtained good results with APC. Taylor et al. used APC in 14 patients with hemorrhagic $\mathrm{CRP}^{61}$. Bleeding episodes ceased in 10 patients $(71 \%)$, although they needed complementary applications. The summarized series are reported in table $2^{61-63}$.

Table 2 - Series and summarized results of patients with hemorrhagic radiation proctitis treated with argon plasma coagulation.

\begin{tabular}{lllll}
\hline Author & $\begin{array}{l}\text { Number of } \\
\text { patients }\end{array}$ & $\begin{array}{l}\text { Follow-up } \\
\text { (months) }\end{array}$ & $\begin{array}{l}\text { Complete } \\
\text { Response }\end{array}$ & $\begin{array}{l}\text { Partial } \\
\text { Response }\end{array}$ \\
\hline Buchi et al. ${ }^{62}, 1987$ & 3 & 7 & $66 \%$ & $100 \%$ \\
Taylor et al. ${ }^{63}, 1993$ & 14 & 35 & $50 \%$ & $50 \%$ \\
O'Connor et al. ${ }^{64}, 1989$ & 5 & 5 & $100 \%$ & - \\
\hline
\end{tabular}


Argon plasma coagulation has proven beneficial in almost all available studies. Use of argon plasma technology for other applications especially in surgery increases the usefulness of the equipment.

Endoscopic treatment through electrocoagulation is simple, widely available, and cheap. Bipolar electrocoagulation may be safer than monopolar. Electrocoagulation and heater probes are readily available at most hospitals without significant additional cost. Because of its ready availability, it is one of our first options for hemorrhagic CRP. Distal telangiectasias can be treated conveniently by this method. All visible lesions should be treated in a single session. The most important technical aspect of telangiectasias ablation is to use the smallest possible amount of energy for coagulation, avoiding formation of deep ulcers. After the initial session of coagulation, an interval should be intervene before reexamination, since coagulated areas need time for healing.

\section{Hyperbaric Oxygen Therapy}

Hyperbaric oxygen (HBO) has been used in the treatment of the RP after previous experiences with other radiation-induced lesions (cystitis and dermatitis) with satisfactory results.

Its mechanism of action is based on the decrease of tissue hypoxia with consequent acceleration of healing process, restoration of local anti-infectious defenses, and directly toxic effects to bacteria.

Four publications reported excellent results with the use of $\mathrm{HBO}$ in 8 patients with hemorrhagic $\mathrm{RP}^{6467}$. However, 2 recent studies demonstrated more modest results. The first of these obtained a $56 \%$ rate of good results for 18 patients ${ }^{68}$. The other was able to achieve $64 \%$ good results in 14 patients $^{69}$. These studies were retrospective with controversial results. There may be recurrences, and it may take a long period of treatment for symptoms to resolve. In addition to the lack of scientific support, HBO is an expensive technique that is still restricted to specialized centers.

\section{CONCLUSIONS}

Many alternative techniques and research with other possible therapeutic agents for the treatment of hemorrhagic CRP, the most frequent chronic complication of radiation injury to the rectum, are currently under investigation ${ }^{71-73}$. The effectiveness of many therapeutic options has still not been shown with solid scientific evidence from controlled trials, and basic research may open a new perspective. Nowadays, the best alternatives for management of hemorrhagic CRP seem to be topical formalin and APC.

Despite all therapeutic strategies available for the management of CRP, the best one remains its prevention. Use of more advanced radiation techniques in the past few decades and introduction of less toxic regimens are good examples that may contribute to a decrease in incidence of CRP. However, the prevalence of CRP may increase as result of widespread use of radiotherapy for cancer treatment.

\section{RESUMO}

COTTI G e col. - Tratamento conservador da retite actínica hemorrágica: uma revisão. Rev. Hosp. Clín. Fac. Med. S. Paulo 58(5): 284-292, 2003.

A retite actínica crônica é uma condição cada vez mais freqüentemente observada como resultado do crescente emprego da radioterapia no tratamento do câncer de órgãos pélvicos. A manifestação hemorrágica da retite actínica é a complicação mais comum dessa doença e seu tratamento é desafiador. Diversas técnicas foram empre- gadas para o tratamento dessa condição e não há evidência satisfatória acerca da melhor forma de controlar os episódios de sangramento de forma eficaz e duradoura. A necessidade de se realizar múltiplas sessões de tratamento conservador bem como a associação de técnicas freqüentemente observada no manejo desses pacientes dificulta a interpretação dos resultados. O objetivo dessa revisão foi avaliar a segurança e a eficácia das alternativas clínicas mais freqüentemente empregadas no controle da retite actínica hemorrágica. Ainda que a falta de es- tudos prospectivos e randomizados comparando duas ou mais alternativas terapêuticas impeça uma conclusão mais definitiva, concluímos que existe suficiente evidência acerca de elevada eficácia e segurança associadas ao emprego da formalina tópica e da coagulação por plasma de argônio no controle do sangramento em pacientes com retite actínica crônica.

DESCRITORES: Retite. Actínica. Hemorrágica. Tratamento. Conservador. 
1. BEARD CJ, PROPERT KJ, RIEKER PP et al. - Complications after treatment with external-beam irradiation in early-stage prostate cancer patients: a prospective multiinstitutional outcomes study. J Clin Oncol 1997; 15:223-229.

2. CROOK J, ESCHE B, FUTTER $\mathrm{N}$ et al. - Effect of pelvic radiotherapy for prostate cancer on bowel, bladder, and sexual function: the patient's perspective. Urology 1996; 47:387394.

3. MONTANA GS, FOWLER WC - Carcinoma of the cervix: analysis of bladder and rectal radiation dose and complications. Int $\mathbf{J}$ Radiat Oncol Biol Phys 1989; 16:95-100.

4. CUNNINGHAM IG - The management of radiation proctitis. Aust N Z J Surg 1980; 50:172-178.

5. HABOUBI NY, SCHOFIELD PF, ROWLAND PL - The light and electron microscopic features of early and late phase radiationinduced proctitis. Am J Gastroenterol 1988; 83:1140-1144.

6. ROTHENBERGER B, LISEHORA GB - Radiation proctitis. Semin Colon Rectal Surg 1993; 4:240-248.

7. AJLOUNI M - Radiation-induced proctitis. Curr Treat Options Gastroenterol 1999; 2:20-26.

8. COIA LR, MYERSON RJ, TEPPER JE - Late effects of radiation therapy on the gastrointestinal tract. Int J Radiat Oncol Biol Phys 1995; 31:1213-1236.

9. DECOSSE JJ, RHODES RS, WENT WB et al. - The natural history and management of radiation induced injury of the gastrointestinal tract. Ann Surg 1969; 170:369-384.

10. GILINSKY NH, BURNS DG, BARBEZAT GO et al. - The natural history of radiation-induced proctosigmoiditis: an analysis of 88 patients. Q J Med 1983; 52:40-53.

11. SMIT WG, HELLE PA, VAN PUTTEN WL et al. - Late radiation damage in prostate cancer patients treated by high dose external radiotherapy in relation to rectal dose. Int J Radiat Oncol Biol Phys 1990; 18:23-29.

12. BERTUCCELLI M, CARTEI F, FALCONE A et al. - Postoperative adjuvant chemoradiotherapy for rectal cancer: analysis of acute and chronic toxicity. Tumori 1997; 83:599-603.

13. VITAUX J - Rectite radique, un diagnostic endoscopique facile, un traitement parfois difficile. Presse Med 1998; 27:1255.

14. WACHTER S, GERSTNER N, GOLDNER G et al. - Endoscopic scoring of late rectal mucosal damage after conformal radiotherapy for prostatic carcinoma. Radiother Oncol 2000; 54:11-19.

15. CHO KH, LEE CK, LEVITT SH - Proctitis after conventional external radiation therapy for prostate cancer: importance of minimizing posterior rectal dose. Radiology 1995; 195:699703.

16. GOLDSTEIN F, KHOURY J, THORNTON JJ et al. - Treatment of chronic radiation enteritis and colitis with salicylazosulfapyridine and systemic corticosteroids. A pilot study. Am J Gastroenterol 1976; 65:201-208.
17. BEM BOUALI A, VARLAN E - Intérêt de lássociation salazopiryne comprimé-lavement dans les colites radiques. Med Chir Dig 1984; 13:559-565.

18. PAJARES GARCIA JM, MORENTO-OTERO R, ROLDAN NUNEZ J et al. - Actinic protocolitis. Clinical, endoscopical, histopathological and therapeutical aspects. A study of 20 patients. Rev Clin Esp 1977; 147:481-484.

19. TRIANTAFILLIDIS JK, DADIOTI P, NICOLAKIS D et al. High doses of 5-aminosalicylic acid enemas in chronic radiation proctitis: comparison with betamethasone enemas. Am J Gastroenterol 1990; 85:1537-1538.

20. KOCHHAR R, PATEL F, DHAR A et al. - Radiation-induced proctosigmoiditis. Prospective, randomized, double-blind controlled trial of oral sulfasalazine plus rectal steroids versus rectal sucralfate. Dig Dis Sci 1991; 36:103-107.

21. ROUGIER PH, ZIMMERMANN P, PIGNON JP et al. - Rectites radiques: efficacité comparée de deux types de corticoids administers localement. Med Chir Dig 1992; 21:91-93.

22. GUL YA, PRASANNAN S, JABAR FM et al. - Pharmacotherapy for chronic hemorrhagic radiation proctitis. World J Surg 2002; 26:1499-1502.

23. LADAS SD, RAPTIS AS - Sucralfate enemas in the treatment of chronic postradiation proctitis. Am J Gastroenterol 1989; 84:1587-1589.

24. BAUM CA, BIDDLE WL, MINER PB JR et al. - Failure of 5aminosalicylic acid enemas to improve chronic radiation proctitis. Dig Dis Sci 1989; 34:758-760.

25. ZAHAVI I, AVIDOR I, MARCUS $\mathrm{H}$ et al. - Effect of sucralfate on experimental colitis in the rat. Dis Colon Rectum 1989; 32:9598

26. KOCHHAR R, SHARMA SC, GUPTA BB et al. - Rectal sucralfate in radiation proctitis. Lancet 1988; 2:400.

27. HENRIKSSON R, FRANZEN L, LITTBRAND B - Effects of sucralfate on acute and late bowel discomfort following radiotherapy of pelvic cancer. J Clin Oncol 1992; 10:969975 .

28. STOCKDALE AD, BISWAS A - Long-term control of radiation proctitis following treatment with sucralfate enemas. Br J Surg 1997; 84:379.

29. TADA M - Treatment of radiation proctitis with sucralfate suspension enema. Gut 1996; 39:A31.

30. O'BRIEN PC, FRANKLIN CI, DEAR KB et al. - A phase III double-blind randomised study of rectal sucralfate suspension in the prevention of acute radiation proctitis. Radiother Oncol 1997; 45:117-123.

31. SASAI T, HIRAISHI H, SUZUKI Y et al. - Treatment of chronic post-radiation proctitis with oral administration of sucralfate. Am J Gastroenterol 1998; 93:1593-1595.

32. KOCHHAR R, SRIRAM PV, SHARMA SC et al. - Natural history of late radiation proctosigmoiditis treated with topical sucralfate suspension. Dig Dis Sci 1999; 44:973-978. 
33. COOK SI, SELLIN JH - Review article: short chain fatty acids in health and disease. Aliment Pharmacol Ther 1998; 12:499. 507

34. SCHEPPACH W, CHRISTL SU, BARTRAM HP et al. - Effects of short-chain fatty acids on the inflamed colonic mucosa. Scand J Gastroenterol Suppl 1997; 222:53-57.

35. PINTO A, FIDALGO P, CRAVO M et al. - Short chain fatty acids are effective in short-term treatment of chronic radiation proctitis: randomized, double-blind, controlled trial. Dis Colon Rectum 1999; 42:788-795

36. MAMEL JJ, CHEN M, COMBS W et al. - Short-chain fatty acids (SCFA) enemas are useful for the treatment of chronic radiation proctitis (Abstract). Gastroenterology 1995; 108:A305.

37. AL-SABBAGH R, SINICROPE FA, SELLIN JH et al. - Evaluation of short-chain fatty acid enemas: treatment of radiation proctitis. Am J Gastroenterol 1996; 91:1814-1816.

38. CHEN FC, KING DW, TALLEY N - Short-chain fatty acid enemas for chronic radiation proctitis: a pilot study (abstrct). Dis Colon Rectum 1996; 39:A34.

39. TALLEY NA, CHEN F, KING D et al. - Short-chain fatty acids in the treatment of radiation proctitis: a randomized, doubleblind, placebo-controlled, cross-over pilot trial. Dis Colon Rectum 1997; 40:1046-1050.

40. DONAHUE LA, FRANK IN - Intravesical formalin for hemorrhagic cystitis: analysis of therapy. J Urol 1989; 141:809-812.

41. BROWN RB - A method of management of inoperable carcinoma of the bladder. Med J Aust 1969; 1:23-24.

42. RUBINSTEIN E, IBSEN T, RASMUSSEN RB et al. - Formalin treatment of radiation-induced hemorrhagic proctitis. Am J Gastroenterol 1986; 81:44-45.

43. SEOW-CHOEN F, GOH HS, EU KW et al. - A simple and effective treatment for hemorrhagic radiation proctitis using formalin. Dis Colon Rectum 1993; 36:135-138

44. MATHAI V, SEOW-CHOEN F - Endoluminal formalin therapy for haemorrhagic radiation proctitis. Br J Surg 1995; 82:190.

45. MIDOES CORREA J, PINTO A, DIAS PEREIRA A et al. Successful treatment of hemorrhagic radiation proctitis with formalin irrigation. Gastroenterology 1994; 106:A254.

46. SACLARIDES TJ, KING DG, FRANKLIN JL et al. - Formalin instillation for refractory radiation-induced hemorrhagic proctitis. Report of 16 patients. Dis Colon Rectum 1996; 39:196-199.

47. BISWAL BM, LAL P, RATH GK et al. - Intrarectal formalin application, an effective treatment for grade III haemorrhagic radiation proctitis. Radiother Oncol 1995; 35:212-215.

48. ISENBERG GA, GOLDSTEIN SD, RESNIK AM - Formalin therapy for radiation proctitis. JAMA 1994; 272:1822.

49. SALVATI EP - Invited commentary. World J Surg 1996; 20:10941095 .

50. ROCHE B, CHAUTEMS R, MARTI MC - Application of formaldehyde for treatment of hemorrhagic radiation-induced proctitis. World J Surg 1996; 20:1092-1094.
51. FARAGHER I, BAILEY H - Topical Formalin: a simple and effective office treatment of hemorrhagic radiation proctitis. Dis Colon Rectum 1997; 40:A28.

52. CHAPUIS P, DENT O, BOKEY E et al. - The development of a treatment protocol for patients with chronic radiation-induced rectal bleeding. Aust N Z J Surg 1996; 66:680-685.

53. MYERS JA, MALL J, DOOLAS A et al. - Absorption kinetics of rectal formalin instillation. World J Surg 1997; 21:886-889.

54. LEUCHTER RS, PETRILLI ES, DWYER RM et al. - Nd: YAG laser therapy of rectosigmoid bleeding due to radiation injury. Obstet Gynecol 1982; 59(6 Suppl):65S-67S

55. VIGGIANO TR, ZIGHELBOIM J, AHLQUIST DA et al. Endoscopic Nd:YAG laser coagulation of bleeding from radiation proctopathy. Gastrointest Endosc 1993; 39:513517.

56. SWAROOP VS, GOSTOUT CJ - Endoscopic treatment of chronic radiation proctopathy. J Clin Gastroenterol 1998; 27:36-40.

57. ALEXANDER TJ, DWYER RM - Endoscopic Nd:YAG laser treatment of severe radiation injury of the lower gastrointestinal tract: long-term follow-up. Gastrointest Endosc 1988; 34:407-411.

58. GRUND KE, STOREK D, FARIN G - Endoscopic argon plasma coagulation (APC) first clinical experiences in flexible endoscopy. Endosc Surg Allied Technol 1994; 2:42-46.

59. SILVA RA, CORREIA AJ, DIAS LM - Argon plasma coagulation therapy for hemorrhagic radiation proctosigmoiditis. Gastrointest Endosc 1999; 50:221-224.

60. FANTIN AC, BINEK J, SUTER WR - Argon beam coagulation for treatment of symptomatic radiation-induced proctitis. Gastrointest Endosc 1999; 49:515-518.

61. TAYLOR JG, DISARIO JA, BUCHI KN - Argon laser therapy for hemorrhagic radiation proctitis: long-term results. Gastrointest Endosc 1993; 39:641-644

62. BUCHI KN, DIXON JA - Argon laser treatment of hemorrhagic radiation proctitis. Gastrointest Endosc 1987; 33:27-30.

63. O'CONNOR JJ - Argon laser treatment of radiation proctitis. Arch Surg 1989; 124:749.

64. CHARNEAU J, BOUACHOUR G, PERSON B et al. - Severe hemorrhagic radiation proctitis advancing to gradual cessation with hyperbaric oxygen. Dig Dis Sci 1991; 36:373-375.

65. MONTOYA L, ANTON X - Radiation proctitis: treatment with hyperbaric oxygen. Undersea Hyper Med 1993; 20:82.

66. MOULIN C, LI V, LOIZZO F et al. - Value of hyperbaric oxygen in the hemostatic treatment of chronic radiation-induced rectosigmoiditis. Gastroenterol Clin Biol 1993; 17:520-521.

67. NAKADA T, KUBOTA Y, SASAGAWA I et al. - Therapeutic experience of hyperbaric oxygenation in radiation colitis. Report of a case. Dis Colon Rectum 1993; 36:962-965.

68. WOO TC, JOSEPH D, OXER H - Hyperbaric oxygen treatment for radiation proctitis. Int J Radiat Oncol Biol Phys 1997; 38:619-622. 
Conservative therapies for hemorrhagic radiation proctitis: a review Cotti G et al.

69. WARREN DC, FEEHAN P, SLADE JB et al. - Chronic radiation proctitis treated with hyperbaric oxygen. Undersea Hyperb Med 1997; 24:181-184.

70. CARL UM, PEUSCH-DREYER D, FRIELING T et al. - Treatment of radiation proctitis with hyperbaric oxygen: what is the optimal number of HBO treatments? Strahlenther Onkol 1998; 174:482-483.

71. YOUNG-FADOK TM - Successful and sustained treatment of chronic radiation proctitis with antioxidant vitamins $\mathrm{E}$ and $\mathrm{C}$. Dis Colon Rectum 2002; 45:150.
REV. HOSP. CLÍN. FAC. MED. S. PAULO 58(5):284-292, 2003

72. GRIGSBY PW, PILEPICH MV, PARSONS CL - Preliminary results of a phase I/II study of sodium pentosanpolysulfate in the treatment of chronic radiation-induced proctitis. Am J Clin Oncol 1990; 13:28-31.

73. JADOT G, VAILle A, MALDONADO J et al. - Clinical pharmacokinetics and delivery of bovine superoxide dismutase. Clin Pharmacokinet 1995; 28:17-25. 